Reprod. Nutr. Dévelop., 1986, 26 (6), 1241-1253.

\title{
In vivo cholesterol synthesis by the rat digestive tract. III. Evaluation of modulating factors
}

\author{
C. LUTTON, Martine PERRODIN, L. E. CARDONA-SANCLEMENTE $\left({ }^{*}\right)$, Colette \\ SÉROUGNE
}

Laboratoire de Physiologie de la Nutrition (1),

Université de Paris-Sud, Bât. 447,

91405 Orsay Cedex, France.

${ }^{*}$ ) Department of Medicine, Universidad Tecnologica de Pereira, A. A 97 Pereira, Colombia.

Summary. Sterol radioactivity was measured in the gastrointestinal tract of rats fed a semi-purified basal diet $(\mathrm{B})$, either enriched with $0.5 \%$ cholesterol $(\mathrm{CH})$ or containing $2 \%$ orotic acid $(\mathrm{O})$. These measurements were taken after a fast of $48 \mathrm{~h}\left(\mathrm{CH}_{\mathrm{F}}\right)$ or after fasting and 4-aminopyrazolopyrimidine (APP) treatment $\left(\mathrm{CH}_{\mathrm{FA}}\right)$; the five groups were killed $70 \mathrm{~min}$ after a subcutaneous injection of $\left[1-{ }^{14} \mathrm{C}\right]$-acetate. Since these results agree with current published data, it is suggested that, although this method is not quantitative, it can give accurate estimates of the qualitative variations of cholesterogenesis in one organ.

Adding cholesterol to the diet had no effect on sterogenesis in the stomach and caecum-colon. Fasting for $48 \mathrm{~h}$ did not affect cholesterogenesis in the caecum-colon, but stomacal sterogenesis was reduced $(50 \%)$. APP treatment, which did not affect cholesterogenesis in the stomach, strongly stimulated (4-fold) cholesterogenesis in the caecum-colon. A slight decrease $(30 \%)$ in intestinal cholesterogenesis was observed after a cholesterol-rich diet. This decrease occurred mainly in villus enterocytes. Fasting reduced cholesterol synthesis 2 to 4 -fold mainly in the proximal intestine, while APP treatment stimulated it until a level higher than in nourished control rats. The level of cholesterogenesis was similar in all the enterocytes collected from duodenum to ileum in APP-treated rats. Since there was high mucosa cell loss (about $50 \%$ ) during the 48-hour APP treatment, total intestinal cholesterogenesis in the $\mathrm{CH}_{\mathrm{FA}}$ rats was not higher than in the $\mathrm{CH}$ animals. Under the present physiological conditions, the feedback inhibition of intestinal cholesterogenesis by luminal bile acids was not clear, while that by luminal cholesterol or by LDL-cholesterol penetrating by specific receptors was modest over a wide range of physiological conditions.

\section{Introduction.}

Our previous studies using ${ }^{3} \mathrm{H}_{2} \mathrm{O}$ or ${ }^{14} \mathrm{C}$-acetate revealed wide differences in the rate of cholesterol synthesis between the different parts of the rat digestive tract (stomach, intestine, caecum and colon) or according to the location of the enterocytes on the villi and in the small intestine (Perrodin and Lutton, 1985 ; Perrodin et al., 1985).

(1) UA 646 CNRS, Unité alliée à l'INSERM (Prof. C. Lutton). 
The present paper deals with the regulation of in vivo cholesterogenesis along the small intestine and on the villi under various experimental conditions known to modify cholesterol balance in the digestive tract. Three mechanisms have been postulated in the regulation of intestinal cholesterogenesis : (1) a feedback inhibition by luminal cholesterol (Bochenek and Rodgers, 1979), (2) a feedback inhibition by bile salts (Dietschy, 1968) and (3) a receptor-dependent LDL uptake leading to suppression of cholesterol synthesis and enhanced cholesterol esterification (Goldstein and Brown, 1977 ; Andersen and Dietschy, 1977). To evaluate the relative influences of these three mechanisms on in vivo regional cholesterol synthesis in the digestive tract, the following experimental conditions were used : ingestion of dietary cholesterol which increases cholesterol and bile acid inputs into the mucosa cells (Chevallier, 1966 ; Dietschy, 1968), fasting which decreases these inputs, ingestion of orotic acid which inhibits lipoprotein secretion by liver (Pottenger and Getz, 1971 ; Kalopissis et al., 1982) and 4-aminopyrazolopyrimidine (APP) treatment which reduces lipoprotein secretion by liver and intestine (Shiff et al., 1971 ; Mahley et al., 1971).

\section{Material and methods.}

Animals and diets.

Adult male Wistar rats weighing $350 \pm 30 \mathrm{~g}$ were used. After weaning they ingested ad libitum a semi-purified diet (Chevallier et al., 1975) whose per cent composition was : sucrose 53 , casein 23 , lard 9.2 , nut oil 0.8 , milk 4 , yeast 2.3 , agar-agar with added vitamins 2.5 , cystine 0.2 .

The rats were kept in an air-conditioned room at $24 \pm 1{ }^{\circ} \mathrm{C}$ with a 12 -hour light/dark cycle $(8 \mathrm{a}$.m. to 8 p.m. and 8 p.m. to 8 a.m.). When 4 months old, they received either the semi-purified basal diet $(B)$, the basal diet and $2 \%$ orotic acid $(\mathrm{O})$ or the basal diet enriched with $0.5 \%$ cholesterol $(\mathrm{CH})$ for three weeks.

\section{Isotopic experiments.}

${ }^{14} \mathrm{C}$ acetate trials. - Groups $\mathrm{B}, \mathrm{CH}$ and $\mathrm{O}$ ingested the diet ad libitum. $\mathrm{CH}_{\mathrm{F}}$ rats were fasted $48 \mathrm{~h}$ and $\mathrm{CH}_{\mathrm{FA}}$ rats were fasted and received two APP injections $(15 \mathrm{mg} / 2 \mathrm{ml}$ of phosphate buffer) daily. The five groups were killed at $10 \mathrm{a} . \mathrm{m}$., 70 min after they had received a subcutaneous injection of $200 \mu \mathrm{Ci}$ of $\left[1-{ }^{14} \mathrm{C}\right]-$ acetate dissolved in $0.2 \mathrm{ml}$ of physiological solution.

The stomach, small intestine and caecum plus colon were removed after the blood had been collected and the circulatory system washed several times with physiological saline. The small intestine was divided into two equal parts or into four quarters. The contents of the stomach, small intestine and caecum plus colon were collected after washing the walls with a Weiser solution (A) $(\mathrm{NaCl}$ $154 \mathrm{mM}$, sodium citrate $27 \mathrm{mM}, \mathrm{KH}_{2} \mathrm{PO}_{4} 8 \mathrm{mM}, \mathrm{Na}_{2} \mathrm{HPO}_{4}, 5.6 \mathrm{mM}, \mathrm{pH} 7.3$ ) for $15 \mathrm{~min}$ at $37^{\circ} \mathrm{C}$ (Weiser, 1973). The moderating action of a second solution (D) $\left(\mathrm{NaCl} 137 \mathrm{mM}, \mathrm{KCl} 2.69 \mathrm{mM}, \mathrm{Na}_{2} \mathrm{HPO}_{4} 8.10 \mathrm{mM}, \mathrm{KH}_{2} \mathrm{PO}_{4} 1.47 \mathrm{mM}\right.$, EDTA $1.5 \mathrm{mM}$, dithiothreitol $0.5 \mathrm{mM}, \mathrm{pH} 7.4)$ at $37^{\circ} \mathrm{C}$ enabled us to collect the 
enterocytes located at the top of the villi (fractions 1-3), in the middle (fractions 4-6) and in the crypts (fractions 7-9).

Isotopic equilibrium trials. - The rats fed the basal or the cholesterolenriched diet received a daily subcutaneous injection of ${ }^{3} \mathrm{H}$-cholesterol $10.2 \mathrm{mg}$, $1 \mu \mathrm{Ci} /$ day/rat) for four weeks while $2.5 \mu \mathrm{Ci} / \mathrm{kg}$ of $\left[4-{ }^{14} \mathrm{C}\right]$-cholesterol were added to the diet. When isotopic equilibrium was obtained, 4 rats (group $\mathrm{CH}_{\mathrm{FA}}$ ) received a daily subcutaneous injection of APP for two days, as above. Fasting control rats $\left(\mathrm{CH}_{\mathrm{F}}\right)$ received phosphate buffer only. Faeces were collected daily. The rats were killed at 10 a.m. The small intestine (contents and wall) was divided into four parts and placed in ethanol. The amount of bile acids in each intestinal sample was determined by the following ratio :

$\frac{\text { radioactivity of acidic fraction }(\mathrm{dpm})}{\text { specific radioactivity of mobile cholesterol }(\mathrm{dpm} / \mathrm{mg})}$

Daily faecal transformation into bile acids ( $\mathrm{mg}$ cholesterol/day) was obtained by the ratio :

radioactivity of faecal acidic fraction (dpm)

specific radioactivity of mobile cholesterol $(\mathrm{dpm} / \mathrm{mg})$

(Lutton and Chevallier, 1972).

Chemical and isotopic techniques.

4-Aminopyrazolopyrimidine (APP) and dithiothreitol were obtained from Sigma and orotic acid from Schuchardt. $\left[1-{ }^{14} \mathrm{C}\right]$-Acetate and $\left|{ }^{3} \mathrm{H}\right|$-cholesterol were purchased from C.E.A.

Chemical techniques for the acetate experiments have been described previously (Perrodin and Lutton, 1985). Briefly, the samples were saponified in alcoholic $2 \mathrm{~N} \mathrm{KOH}$ for $2 \mathrm{~h}$ and the sterols were extracted with petroleum ether and precipitated by digitonin (Sperry and Webb, 1950). After extensive washings of the digitonide complex, the sterols were quantified and we used a liquid scintillation spectrometer (MR 300 Kontron) with a low background to measure the radioactivity in a PPO/dimethyl POPOP/toluene solution in glass flasks. DNA was measured as described by Croft and Lubran (1965) and proteins were measured according·to Gornall et al. (1949).

\section{Results.}

The amounts of cholesterol in the small intestine and cholesterol concentrations in the plasma and intestine of rats receiving a basal (B) diet, basal $+0.5 \%$ cholesterol $(\mathrm{CH})$ or basal $+2 \%$ orotic acid $(\mathrm{O})$ and $48 \mathrm{~h}$ of fasting $\left(\mathrm{CH}_{\mathrm{F}}\right)$ or $48 \mathrm{~h}+\mathrm{APP}$ treatment $\left(\mathrm{CH}_{\mathrm{FA}}\right)$ are listed in table 1. A significant decrease of plasma cholesterol was observed after orotic acid ingestion. A cholesterol-rich diet doubled cholesterolemia. After a fast of $48 \mathrm{~h}$, plasma cholesterol dropped to $50 \%$ of the control value and to less than $15 \mathrm{mg}$ per $100 \mathrm{ml}$ after APP treatment. Cholesterol concentration in the small intestine did not change significantly after 
orotic acid was added, 48-hour fast or APP administration. It increased slightly $(20 \%)$ in rats fed the cholesterol-enriched $(\mathrm{CH})$ diet. The total amount of cholesterol in the intestine was reduced significantly by fasting $\left(\mathrm{CH}_{F}\right)$ and the APP treatment $(8.2 \mathrm{mg}$ vs $19.4 \mathrm{mg}$ in fed rats) where a considerable number of mucosal cells were lost.

TABLE 1

Cholesterol level in the small intestine and cholesterol concentrations in the plasma and intestine of rats fed with experimental diets.

\begin{tabular}{|c|c|c|c|c|}
\hline \multirow{2}{*}{$\begin{array}{l}\text { Diet or } \\
\text { treatment }\end{array}$} & \multirow{2}{*}{ Symbol } & \multirow{2}{*}{$\frac{\text { Plasma }}{(\mathrm{mg} / \mathrm{ml})}$} & \multicolumn{2}{|c|}{ Intestine } \\
\hline & & & $(\mathrm{mg} / \mathrm{g})$ & (mg/whole organ) \\
\hline Basal & $B$ & $0.66+0.01^{a}$ & $1.59+0.17$ & $16.8+1.1$ \\
\hline Basal $+2 \%$ orotic acid & 0 & $0.39 \pm 0.02^{b}$ & $1.47 \pm 0.16$ & $14.2 \pm 0.8$ \\
\hline Basal $+0.5 \%$ cholesterol & $\mathrm{CH}$ & $1.11 \pm 0.20^{\mathrm{b}}$ & $2.12 \pm 0.23$ & $19.4 \pm 1.2$ \\
\hline $\begin{array}{l}\text { Basal }+0.5 \% \text { cholesterol } \\
48 \text { hrs fasting }\end{array}$ & $\mathrm{CH}_{F}$ & $0.65 \pm 0.05^{c}$ & $1.49 \pm 0.21$ & $12.7 \pm 1.0^{c}$ \\
\hline $\begin{array}{c}\text { Basal }+0.5 \% \text { cholesterol } \\
48 \text { hrs APP }\end{array}$ & $\mathrm{CH}_{\mathrm{FA}}$ & $0.14 \pm 0.01^{d}$ & $1.37 \pm 0.19$ & $8.2 \pm 0.5^{d}$ \\
\hline
\end{tabular}

a - Mean $\pm \mathrm{SEM}\left(\mathrm{n}=3\right.$ for $\mathrm{B}, \mathrm{O}, \mathrm{CH} ; \mathrm{n}=4$ for $\left.\mathrm{CH}_{\mathrm{F}}, \mathrm{CH}_{\mathrm{FA}}\right) ; \mathrm{b}$ - Significantly different $(\mathrm{P}<0.05)$ versus $\mathrm{B} ; \mathrm{c}$ - Significantly different $(\mathrm{P}<0.05)$ versus $\mathrm{CH} ; \mathrm{d}$ - Significantly different $(\mathrm{P}<0.05)$ versus $\mathrm{CH}_{\mathrm{F}}$.

TABLE 2

Sterol radioactivity (dpm) in the stomach, small intestine (divided into two halves) and caecum plus colon of rats 70 min after a subcutaneous injection of ${ }^{14} \mathrm{C}$-acetate $(100 \mu \mathrm{Ci})$.

\begin{tabular}{|c|c|c|c|c|c|}
\hline & \multirow{2}{*}{ Stomach } & \multicolumn{3}{|c|}{ Small intestine } & \multirow{2}{*}{ Caecum-colon } \\
\hline & & first half & second half & Sum & \\
\hline $\begin{array}{l}\mathrm{B} \\
\mathrm{O} \\
\mathrm{CH} \\
\mathrm{CH}_{F} \\
\mathrm{CH}_{\mathrm{FA}}\end{array}$ & $\begin{array}{c}7415 \pm 605^{\mathrm{a}} \\
\text { n.d. } \\
10525 \pm 1603 \\
5099 \pm 551^{\mathrm{c}} \\
7424 \pm 873\end{array}$ & $\begin{array}{r}137450 \pm 7832 \\
113978 \pm 8879 \\
85105 \pm 1909^{\mathrm{b}} \\
20827 \pm 2634^{\mathrm{c}} \\
85723 \pm 16643^{\mathrm{d}}\end{array}$ & $\begin{array}{l}49664 \pm 10608 \\
38904 \pm 2759 \\
44233 \pm 6622 \\
15260 \pm \quad 639^{\circ} \\
27906 \pm 3228^{d}\end{array}$ & $\begin{array}{r}187114 \pm 17260 \\
152882 \pm 14908 \\
129337 \pm 7063^{b} \\
36087 \pm 3009^{c} \\
113629 \pm 18950^{d}\end{array}$ & 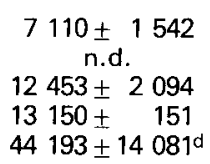 \\
\hline
\end{tabular}

a - Mean $\pm \operatorname{SEM}\left(n=3\right.$ for $\mathrm{B}, \mathrm{O}, \mathrm{CH} ; \mathrm{n}=4$ for $\mathrm{CH}_{F}, \mathrm{CH}_{F A}$ ); b - Significantly different $(P<0.05)$ versus $B ; C$ - Significantly different $(P<0.05)$ versus $C H$; $d$ - Significantly different $(\mathrm{P}<0.05\}$ versus $\mathrm{CH}_{\mathrm{F}} ;$ nd : not determined.

Figure 1 shows cholesterol levels in enterocytes located in different parts of the small intestine and villi in $\mathrm{B}, \mathrm{CH}, \mathrm{CH}_{\mathrm{F}}$ and $\mathrm{CH}_{\mathrm{FA}}$ rats. In the two last groups (48-hour fast), the mean cholesterol contents in the enterocytes (expressed in $\mathrm{mg}$ of cholesterol per $\mathrm{mg}$ of DNA) were not significantly different and reached $0.45 \pm 0.02(n=36)$ and $0.40 \pm 0.03(n=24)$, respectively, while the mean cholesterol content of $B$ rats reached $0.54 \pm 0.01(n=96)$. In rats fed a cholesterol-rich diet, these mean contents were $0.78 \pm 0.04$ ( $n=34$ ). In $\mathrm{CH}$ rats particularly, the amount of enterocyte cholesterol seemed to increase from crypt 
to top at all sites in the small intestine. However, because of the small number of data ( $n=3$ ) for each group, no statistical differences were evident between each Weiser fraction. But when the mean cholesterol content of the crypt cells ( $n=12$ ) was compared to that of villus cells $(n=12$ or 32 ), it was found to be significantly higher in the top cells in all four groups (B: $0.60 \pm 0.02$ vs $0.45 \pm 0.01 ; \mathrm{CH}: 0.91 \pm 0.06$ vs $0.62 \pm 0.08 ; \mathrm{CH}_{\mathrm{F}}: 0.50+0.03$ vs $0.36 \pm$ $0.33 ; \mathrm{CH}_{\mathrm{FA}}: 0.40 \pm 0.02$ vs $\left.0.31 \pm 0.04\right)$. Moreover, the cholesterol content of top enterocytes from the $2 \mathrm{nd}$, 3rd and 4th quarters and of intermediate cells from the 2 nd and 3 rd quarters was significantly higher in $\mathrm{CH}$ than in $\mathrm{B}$ rats.

Table 2 shows sterol radioactivities in the stomach, small intestine and caecum-colon $70 \mathrm{~min}$ after ${ }^{14} \mathrm{C}$-acetate was administered. Similar sterol radio-

$$
1^{\text {si }} \quad 2^{\text {nd }} \quad 3^{\text {rd }} \quad 4^{\text {th }}
$$
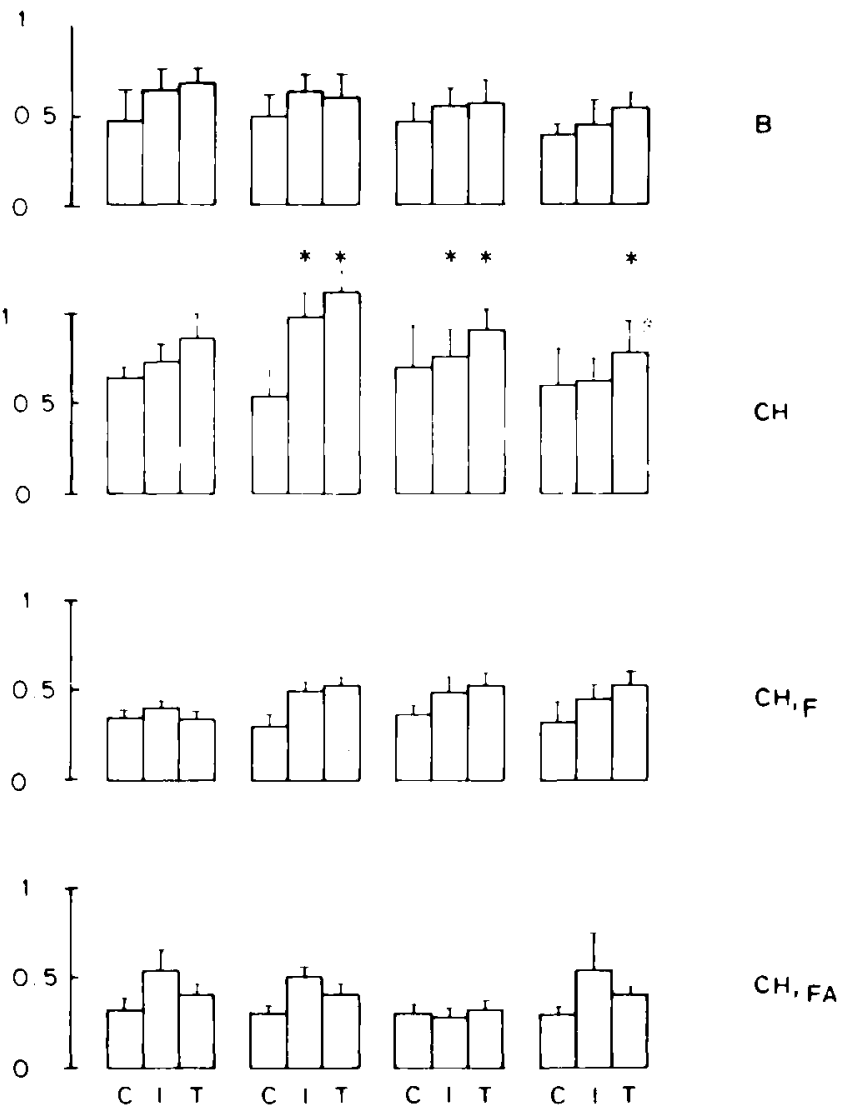

FIG. 1. - Cholesterol concentration (mg per mg of DNA) in the various enterocytes of $\mathrm{B}, \mathrm{CH}, \mathrm{CH}_{F}$ and $\mathrm{CH}_{F A}$ rats. The cells were collected after the small intestine was divided into four equal quarters $\left(1^{\text {st }}, 2^{\text {nd }}, 3^{\text {rd }}, 4^{\text {th }}\right) . C$ : crypt cells (fractions $7-9$, Weiser's method) $; 1$ : intermediate cells (fractions 4-6, Weiser's method); $T$ : top cells (fractions 1-3, Weiser's method).

The reported values are mean $\pm S E M\left(n=8\right.$, group $B, n=3$, groups $\left.\mathrm{CH}, \mathrm{CH}_{F}, \mathrm{CH}_{\mathrm{FA}}\right)$.

* Significantly different $(\mathrm{P}<0.05)$ versus $\mathrm{B}$ rats. 
activity was observed in the stomach of $\mathrm{B}, \mathrm{CH}$ and $\mathrm{CH}_{\mathrm{FA}}$ rats and a lower one after fasting $\left(\mathrm{CH}_{\mathrm{F}}\right)$. On the contrary, intestinal sterol radioactivity varied with the experimental conditions. Dietary cholesterol addition led to a $39 \%$ decrease in sterol radioactivity in the proximal small intestine $(\mathrm{CH}$ vs $\mathrm{B})$, orotic acid did not significantly change sterol radioactivity in the small intestine; 48-hour fasting reduced it by $85 \%$ in the proximal part and by $70 \%$ in the distal part. APP treatment stimulated sterol radioactivity in the first (4-fold) and second (2-fold) halves of the intestine compared to fasting rats. The sterol radioactivity in the caecum plus colon did not change after 48-hour fasting or cholesterol addition but increased strongly (3-fold) after fasting + APP treatment.

Cholesterol radioactivities in the enterocytes collected from the crypt to villus and from duodenum to distal ileum are shown in figure 2 (fed rats : $\mathrm{B}$ and $\mathrm{CH}$ ) and in figure 3 (48-hour fasted rats: $\mathrm{CH}_{\mathrm{F}}$ and $\mathrm{CH}_{\mathrm{FA}}$ ). Similar patterns of sterol radioactivity were found in the mucosa of rats fed a semi-purified diet with or without $0.5 \%$ cholesterol. Whereas total cholesterol radioactivity in the small

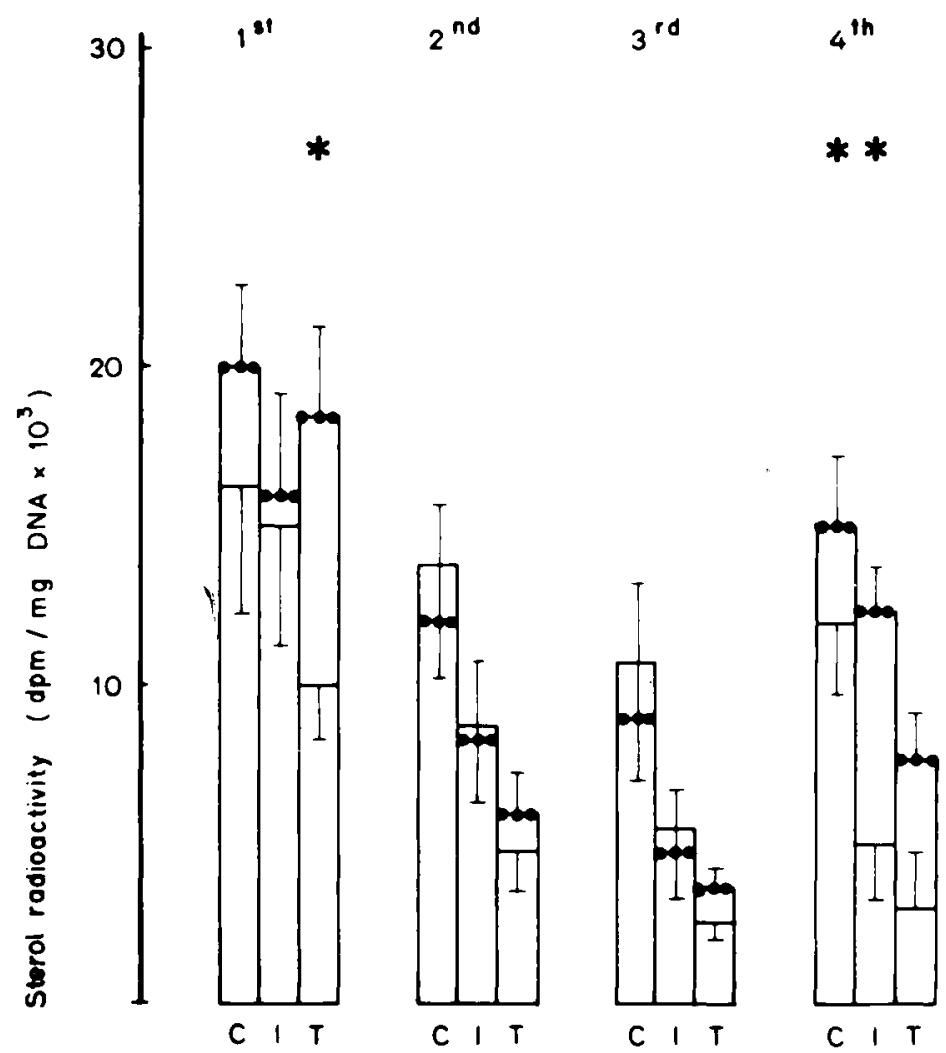

FIG. 2. - Profile of sterol radioactivity (dpm per $\mathrm{mg}$ of DNA) in the enterocytes of rats (groups $B$ and $\left.\mathrm{B}_{\mathrm{CH}}\right)$ receiving a subcutaneous injection of ${ }^{14} \mathrm{C}$-acetate $(100 \mu \mathrm{Ci})$.

$-1-\mathrm{B} ; \frac{\mathrm{CH}}{0}$

* Significantly different $(P<0.05)$ versus $B$.

C, I, T: see legend fig. 1 . 
intestine of $\mathrm{CH}$ rats was slightly lower than that of intestinal cholesterol in the controls, the values of cholesterol radioactivity per cell (dpm/mg DNA) were significantly lower in $\mathrm{CH}$ than in $\mathrm{B}$ rats only in certain samples. This was due to the relatively wide variations between individual results. 48-hour fasting resulted in a considerable decrease of intestinal cholesterol radioactivity according to cell localization (fig. 3). Cholesterol radioactivity in crypt and intermediate cells collected from the first three quarters of the small intestine was 3 to 5-fold less in fasting (fig. 3) than in nourished (fig. 2) rats. It dropped 1.5 to 3 -fold in top cells from the proximal small intestine and was insignificant in top enterocytes from the distal ileum. APP treatment (fig. 3) enhanced cholesterol radioactivity 5 to 10 -fold in all the enterocytes collected by the Weiser method.

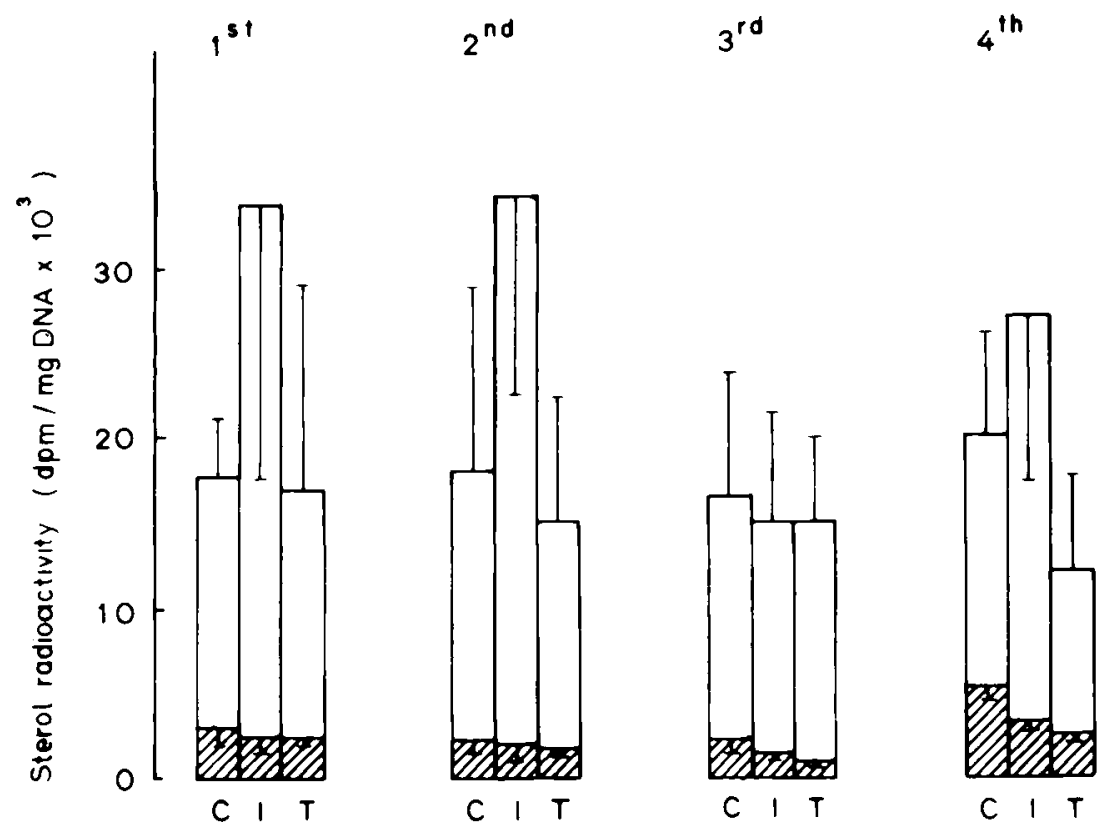

FIG. 3. - Profile of sterol radioactivity (dpm per $\mathrm{mg}$ of DNA) in the enterocytes of rats (groups $\mathrm{CH}_{\mathrm{F}}$ and $\left.\mathrm{CH}_{\mathrm{FA}}\right)$ receiving a subcutaneous injection of ${ }^{14} \mathrm{C}$-acetate $(100 \mu \mathrm{Ci})$.

C, I, T: see legend fig. 1.

III $\mathrm{CH}_{\mathrm{F}} ; \square \mathrm{CH}_{\mathrm{FA}}$.

Table 3 shows the amounts of total bile acids found in the luminal contents of the small intestine, caecum or colon and the daily faecal bile acid loss measured by the isotopic equilibrium method (Lutton and Chevallier, 1972) in B, $\mathrm{CH}, \mathrm{CH}$ fasting rats $\left(\mathrm{CH}_{\mathrm{F}}\right)$ and APP-treated rats $\left(\mathrm{CH}_{\mathrm{FA}}\right)$. The daily faecal loss of bile acids, which was similar in groups $\mathrm{CH}_{F}$ and $\mathrm{CH}_{\mathrm{FA}}$ before treatment (fast only or fast + APP), underwent the same $70 \%$ reduction during the second experimental day. At sacrifice time, the amounts of bile acids in the intestinal lumen were not significantly different in $\mathrm{CH}_{F}$ and $\mathrm{CH}_{F A}$ rats. Only the bile acid contents in the luminal colon and caecum-colon in rats receiving APP were lower than those 


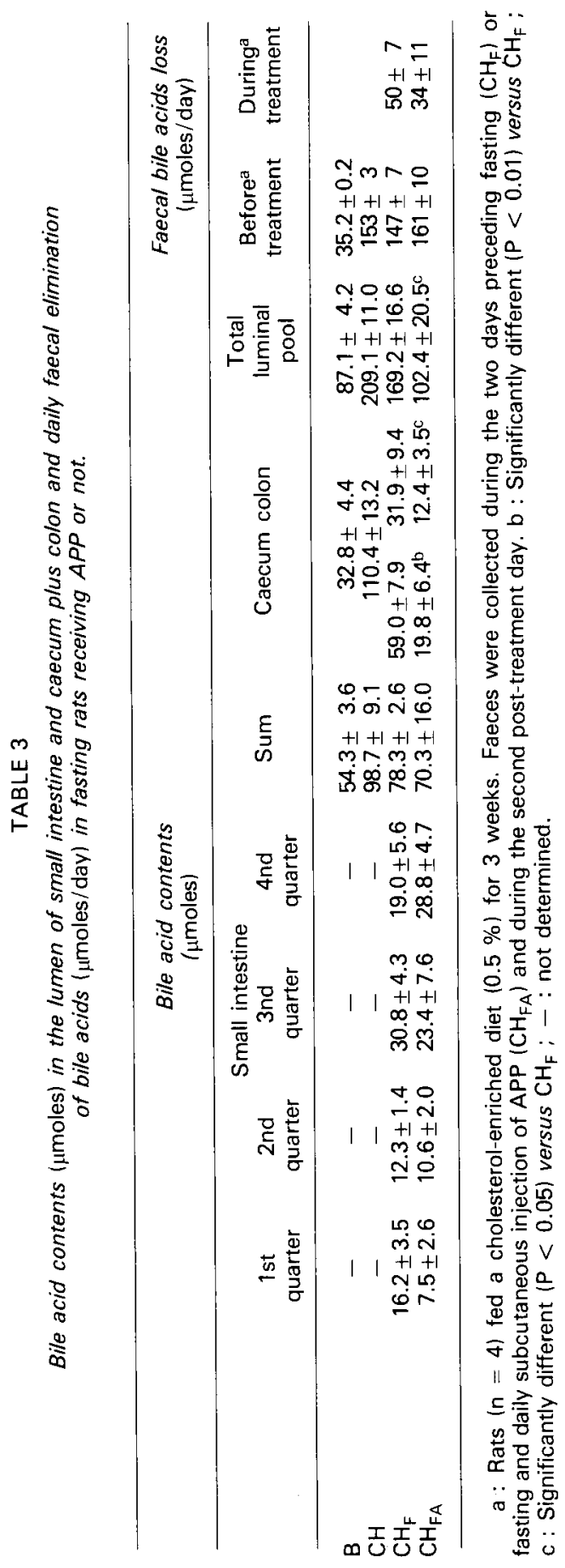


of fasting rats (19.8 and $12.4 \mu$ moles $v s 59.0$ and $31.9 \mu$ moles, respectively). The mass of bile acids found in the small intestine and lower digestive tract contents was higher in $\mathrm{CH}_{F}(78.3 \pm 2.6$ and $90.9 \pm 8.5 \mu$ moles, respectively) than in $\mathrm{B}$ (54 \pm 4 and $33 \pm 4$ moles, respectively) rats but lower than in $\mathrm{CH}$ (98.7 \pm $9.1 \mu$ moles) rats.

\section{Discussion.}

Although the absolute rates of cholesterol synthesis in the different organs could not be measured by ${ }^{14} \mathrm{C}$-acetate incorporation into sterols, this method was shown to be quite suitable for comparative studies of cholesterogenesis in a particular organ or cell type (Andersen and Dietschy, 1979). In a previous in vivo study where the radioactivity in gastro-intestinal sterols was measured after $\left[1-{ }^{14} \mathrm{C}\right]$-acetate or tritiated water administration in cholesterol-fed Wistar rats, the results were qualitatively similar with the two precursors (Perrodin and Lutton, 1985). Furthermore, after intravenous infusion of $\left[1,2-{ }^{13} \mathrm{C}\right]$-acetic acid, the distribution of ${ }^{13} \mathrm{C}$ atoms in newly-synthesized cholesterol was assessed in liver and intestine of male or female rats submitted to various physiological conditions. The results indicated that cholesterol was synthesized from acetyl CoA which was generally more ${ }^{13} \mathrm{C}$-enriched in intestine than in liver, but that the ${ }^{13} \mathrm{C}$ labelling pattern for intestinal cholesterol was apparently the same, whatever the conditions used (Férézou et al., 1986). The present study therefore suggests that changes in the radioactivity of gastrointestinal sterols during experimental manipulation are mainly due to modifications in the rate of cholesterogenesis and not to various dilutions of the acetyl CoA pool.

The relative contribution of the three mechanisms proposed for cholesterogenesis regulation in the small intestine (feedback inhibition by luminal cholesterol or by bile acids and receptor-dependent and receptor-independent LDL uptake) have been successively examined in the various parts of the digestive tract.

Since no luminal cholesterol or bile acid uptake has been demonstrated in the stomach (Chevallier and Lutton, 1972 ; Thomson and Dietschy, 1981), stomachal sterogenesis could only be affected by a mechanism such as that described by Goldstein and Brown (1977). However, similar sterol radioactivities were measured in the stomachs of $\mathrm{B}, \mathrm{CH}$ or $\mathrm{CH}_{\mathrm{FA}}$ rats in which the lipoprotein patterns were very different (Sérougne et al., 1984 ; Shiff et al., 1971). Even fasting apparently has little effect of sterogenesis in the stomach.

It is known that a part of the bile acid pool is absorbed in the caecum-colon (Norman and Sjövall, 1958 ; Olivecrona and Sjövall, 1959 ; Lack, 1979). But, in the presence of various caecal and colonic bile acid contents, no changes occurred in the sterol radioactivity in the caecum-colon of $\mathrm{B}, \mathrm{CH}$ or $\mathrm{CH}_{F}$ rats. The only variation in colonic sterol radioactivity was found in $\mathrm{CH}_{\mathrm{FA}}$ rats in which caecal and colonic bile acid contents were higher than in control rats whereas sterogenesis was increased 3-fold. This in vivo stimulation of colonic and caecal 
cholesterogenesis agrees with in vitro determinations (Andersen and Dietschy, 1977). It has been interpreted as the suppression of the LDL-dependent feedback system since APP causes considerable reduction in plasma cholesterol content and an increase in HMG CoA reductase radioactivity which is reversed by LDL infusion.

The present data show that in vivo intestinal cholesterogenesis was little affected by relatively large modifications in the bile acid and cholesterol contents of the small intestine or by plasma lipoprotein concentration. A cholesterol-rich $(0.5 \%)$ diet lowered total intestinal sterogenesis only slightly $(30 \%)$ without greatly affecting the cholesterogenesis pattern from duodenum to ileum. Expressed as sterolspecific radioactivity (dpm/ $\mathrm{mg}$ of cholesterol) or as sterol radioactivity per cell (dpm/mg of DNA), a decreasing gradient was observed from the crypt to the top cells and along the intestine in both $\mathrm{B}$ and $\mathrm{CH}$ rats, while the highest sterol synthesis occurred in the 1st and 4th quarters of the small intestine. This agrees with previous data obtained by $\left[1-{ }^{14} \mathrm{C}\right]$-acetate of ${ }^{3} \mathrm{H}_{2} \mathrm{O}$ administration in male Wistar or female Sprague-Dawley rats (Perrodin and Lutton, 1985; Stange and Dietschy, 1983). In rats fed a cholesterol-rich diet, however, this reduction occurred mainly in the top cells where most cholesterol absorption takes place, while cholesterol synthesis in the crypt cells seemed unaffected. Consequently, the crypt-villus decreasing gradient of cholesterogenesis was more pronounced in $\mathrm{CH}$ rats than in the controls. We also wish to emphasize that, under our conditions, there was a greater difference in the rate of cholesterogenesis between a crypt and a top cell (in the second or third quarter, for example) than between a crypt cell in the proximal small intestine and one in the distal part ( 3 to 6 -fold vs 2 -fold). Orotic acid in the diet induces no change in total intestinal cholesterogenesis, while plasma cholesterol decreases mainly in the VLDL and HDL fractions (Pottenger and Getz, 1971 ; Kalopissis et al., 1982). 48-hour fasting reduced cholesterogenesis by 6 to 3 -fold in the proximal and distal small intestine, respectively, in agreement with Panini's results (1979) on the distribution of 3-OH- $\beta$-methylglutaryl $\mathrm{CoA}$ reductase radioactivity in the ileal cells. However, it should be stressed that crypt cells are more sensitive to fasting than top cells and duodenal enterocytes more than distal ileum cells. When fasting rats received APP, cholesterol radioactivity in the mucosal cells (in $\mathrm{dpm} / \mathrm{mg}$ of DNA) was multiplied by 5 to 10 and total sterol radioactivity (dpm/intestine) by $4 \mathrm{vs}$ fasting rats, and it reached $88 \%$ of the total radioactivity in the intestinal sterol of $\mathrm{CH}$ rats. This was due to a high loss of mucosal cells during the 2-day APP treatment. More than $50 \%$ of the mucosal cells (mainly top cells) in APP rats were sloughed into the lumen without replacement during the treatment. This explains why the total sterol radioactivity in the intestine was not stimulated as much as the radioactivity per cell, and it probably also explains the apparent disappearance of the gradient in enterocyte cholesterogenesis.

Several data argue againts a significant role of luminal bile acids as direct in vivo regulators of intestinal cholesterol synthesis. A 2-fold increase of the bile acids in the lumen ( $\mathrm{CH}$ rats) led to only a slight decrease in intestinal cholesterogenesis (present data). When luminal bile acids are abolished (bile duct ligation for 1 to 3 weeks), intestinal sterogenesis increases only 1.5 to 3 -fold 
(Dietschy, 1968). A 12-hour infusion of bile in APP rats does not lower intestinal cholesterogenesis (data not shown). The stimulation of intestinal cholesterogenesis in APP-treated $v s$ fasting rats was not due to a decrease in the luminal bile acids. Furthermore, cholesterol synthesis is not inhibited in cultured intestinal cells (Schneider et al., 1979) and simultaneous feeding of cholesterol and cholestyramine does not increase jejunal cholesterol synthesis in isolated cells as compared with feeding cholesterol alone (Stranberg et al., 1983).

Several arguments have been proposed in favour of the regulation of intestinal cholesterol synthesis by luminal and/or plasma cholesterol; several authors concluded that an increase in cell cholesterol contents, particularly in microsomes, induces a reduction in HMGCoA reductase activity and intestinal cholesterogenesis (Venkatesan and Mitropoulos, 1982). Moreover, the feedback mechanism initially described by Goldstein and Brown in cultured fibroblasts has been implicated in the regulation of intestinal cholesterol synthesis. APP treatment, which induces a pronounced hypocholesterolemia without VLDL and very few LDL and HDL (Shiff et al., 1971), enhances in vitro (Andersen and Dietschy, 1977) and in vivo (our results) acetate incorporation and HMG-CoA reductase activity in isolated cells (Panini et al., 1979). These facts have generally been interpreted as a good illustration of the Brown and Goldstein feedback mechanism. However, APP could modify HMG-CoA reductase activity by direct action on cell metabolism, as previously discussed by Panini. APP also has an inhibitory effect on cholesterol and lipid uptakes in the enterocyte (Krause et al., 1981), thus lowering cell cholesterol contents (see above). Moreover, specific high-density lipoprotein receptors have been identified in isolated cells (Suzuki et al., 1983) but their effect on cholesterol synthesis is not yet known. Stange and Dietschy observed no changes in LDL uptake in rat intestine despite major experimental changes in intestinal cholesterogenesis. On the contrary, Pardy and Field (1984), using surgically-joined parabiont hypothyroid rats, concluded in favour of a lipoprotein cholesterol regulation of intestinal cholesterol synthesis.

Finally, our data indicate that cholesterogenesis in newly-formed crypt enterocytes is unaffected by luminal bile acid and only slightly modified by a wide range of ingested cholesterol and of plasma cholesterol concentrations. We have also shown that part of the biosynthetic capacity of the intestinal cell is progressively lost during cell migration in the villi but that the degree of loss depends on the localization of the cell on the small intestine.

Reçu en mars 1986. Accepté en juillet 1986.

Acknowledgements. - The authors wish to thank M. Moqué for the illustrations and Mrs Boivin for typing the paper.

Résumé. Synthèse de cholestérol dans le tractus digestif du Rat. III. Facteurs de régulation.

Soixante-dix minutes après l'administration sous-cutanée d'acétate ${ }^{14} \mathrm{C}$, la radioactivité des stérols du tractus gastro-intestinal a été mesurée chez des rats ingérant un régime 
semi-synthétique de base enrichi $(0.5 \%$ ) ou non en cholestérol (groupes $\mathrm{CH}$ et $\mathrm{B}$ ), contenant $2 \%$ d'acide orotique (groupe $\mathrm{O}$ ), ou chez des rats à jeun $48 \mathrm{~h}\left(\mathrm{CH}_{\mathrm{F}}\right)$ et recevant une injection quotidienne de 4-aminopyrazolopyrimidine $\left(\mathrm{CH}_{F A}\right)$. Le fait que les résultats obtenus soient en accord avec les données de la littérature suggère que cette approche bien que non quantitative, permet d'apprécier les variations de la cholestérogenèse au niveau d'un organe.

L'addition de cholestérol à l'alimentation n'a pas d'effet sur la synthèse du cholestérol de l'estomac et du cæcum-colon. Il en est de même d'un jeûne de 48 heures au niveau du cæcum-colon tandis que celui-ci abaisse la stérogenèse stomacale de $50 \%$ environ. L'administration d'APP - sans effet sur la cholestérogenèse de l'estomac - stimule fortement (facteur 4) celle du cæecum-colon. Une modeste diminution $(30 \%)$ de la synthèse du cholestérol dans la muqueuse intestinale est observée après l'ingestion d'un régime riche en cholestérol, inhibition ayant lieu essentiellement dans les entérocytes du sommet des villosités. En conséquence, le gradient décroissant de la cholestérogenèse dans l'entérocyte en fonction de sa position sur la villosité (crypte-sommet) est plus accentué chez le Rat ingérant un régime riche en cholestérol. Le jeûne réduit (d'un facteur 2 à 4 ) la synthèse de cholestérol dans l'intestin grêle (en particulier proximal) tandis que l'APP la stimule à un niveau plus élevé que chez le rat nourri et égal dans tous les entérocytes recueillis du duodénum à l'iléum. Une perte de près de $50 \%$ des cellules de la muqueuse étant constatée pendant les $48 \mathrm{~h}$ d'administration d'APP, la cholestérogenèse totale de l'intestin grêle des rats $\mathrm{CH}_{\mathrm{FA}}$ n'est cependant pas plus élevée que celle des rats $\mathrm{CH}$. Dans les conditions physiologiques courantes, le rôle de contrôle de la cholestérogenèse proposé pour les acides biliaires du lumen apparaît négligeable. Celui du cholestérol luminal ou le mécanisme décrit initialement par Brown et Goldstein reste modeste pour une large gamme de conditions physiologiques.

\section{References}

ANDERSEN J. M., DIETSCHY J. M., 1977. Regulation of sterol synthesis in 15 tissues of rat. II. Role of rat and human high and low density plasma lipoproteins and of rat chylomicron remnants. J. biol. Chem., 252, 3652-3659.

ANDERSEN J. M., DIETSCHY J. M., 1979. Absolute rates of cholesterol biosynthesis in extrahepatic tissues with ${ }^{3} \mathrm{H}$-labeled water and ${ }^{14} \mathrm{C}$-labeled substrates. J. Lipid Res., 19, 740-752.

BOCHENEK W. J., RODGERS J. B., 1979. Dietary regulation of 3-hydroxy-3-methylglutaryl CoA reductase from rat intestine. Biochim. Biophys. Acta, 575, 57-62.

CHEVALLIER F., 1966. Vitesses des processus de renouvellement du cholestérol contenu dans son espace de transfert chez le rat. II. Influence de la concentration du cholestérol alimentaire dans le cas d'un régime semi-synthétique témoin. Bull. Soc. Chim. biol., 48, 715-729.

CHEVALLIER F., LUTTON C., 1972. Mouvements des stérols dans le tube digestif du rat. Absorption du cholestérol de synthèse. Biochim. Biophys. Acta, 274, 382-411

CHEVALLIER F., SÉROUGNE C., CHAMPARNAUD G., 1975. Effet upon brain weight and cholesterol content of maintaining rats of various ages at constant weight. J. Nutr., 105, 1003-1011.

CROFT D. N., LUBRAN M., 1965. The estimation of deoxyribonucleic acid in the presence of sialic acid : application to analysis of human gastric washings J. Biochem., 95, 612-620.

DIETSCHY J. M., 1968. The role of bile salts in controling the rate of intestinal cholesterogenesis. J. clin. Invest., 47, 286-300.

FÉRÉZOU J., SULPICE J. C., LUTTON C., 1986. Evidence for different isotopic enrichments of acetyl-CoA used for cholesterol synthesis in the liver and intestine : a study in the rat by mass fragmentography after intravenous infusion of $\left|{ }^{13} \mathrm{C}\right|$ acetate. Biochim. Biophys. Acta, 875, 227-235.

GOLDSTEIN J. L., BROWN M. S., 1977. The LDL pathway and its relation to atherosclerosis. Ann. Rev. Biochem., 46, 897-930.

GORNALL A. T., BARDAWILL C. J., DAVID M. M., 1949. Determination of serum proteins by means of the biuret reaction. J. biol. Chem., 177,751 .

KALOPISSIS A. D., GRIGLIO S., LE LIEPVRE X., 1982. Intestinal very-low-density lipoprotein secretion in rats fed various amounts of fat. Biochim. Biophys. Acta, 711, 33-39. 
KRAUSE B. R., SLOOP C. H., ROHEIM P. S., 1981. Lipid absorption in unanesthetized, unrestrained rats. Effects of 4-aminopyrazolopyrimidine and ethynyl estradiol. Biochim. Biophys, Acta, 665, 165-169.

LACK L., 1979. Properties and biological singificance of the ileal bile salt transport system. Environ. Health Perspect, 33, 79-90.

LUTTON C., CHEVALLIER F., 1972. Vitesse des processus de renouvellement du cholestérol contenu dans son espace de transfert chez le Rat. III. Modifications et étude cinétique de la méthode d'équilibre isotopique. Biochim. Biophys. Acta, 255, 762-779.

MAHLEY R. W., BENNETT B. D., MORRI D. J., GRAY M. E., THISTLETHWAITE W., LE QUIRE V. S., 1971. Lipoproteins associated with the Golgi apparatus isolated from epithelial cells of rat small intestine. Lab. Invest., 25, 435-444.

NORMAN A., SJÖVALL J., 1958. On the transformation and enterohepatic circulation of cholic acid in the rat. J. biol. Chem., 233, 872-885.

OLIVECRONA T., SJÖVALL T., 1959. Bile acids in rat portal blood. Acta physiol. scand, 46. 284-290.

PANINI S. R., LEHRER G., ROGERS D. H., RUDNEY H., 1979. Distribution of 3-OH-3-methylgluraryl CoA reductase and alkaline phosphatase activities in isolated ileal epithelial cells of fed, fasted, cholestyramine-fed and 4-aminopyrazolo (3,4-d) pyrimidine-treated rats. J. Lipid Res., 20, 879-889.

PARDY B. H., FIELD F. J., 1984. Regulation of acylcoenzyme A cholesterol acyltranferase and 3-hydroxy-3-methylglytaryl coenzyme $A$ reductase activity by lipoproteins in the intestine of parabiont rats. J. clin. Invest., 74, 351-357.

PERRODIN M., LUTTON C., 1985. In vivo cholesterol synthesis by the rat digestive tract. I. A topological study. Reprod. Nutr. Dévelop., 25, 647-657.

PERRODIN M., SÉROUGNE C., LUTTON C., 1985. In vivo cholesterol synthesis by the rat digestive tract. II. A study of turnover. Reprod. Nutr. Dévelop., 25, 659-669.

POTTENGER L. A., GETZ G. S., 1971. Serum lipoprotein accumulation in the livers of orotic acidfed rats. J. Lipid Res., 12, 450-459.

SÉROUGNE C., FEREZOU J., RUKAJ A., 1984. Effects of excess dietary L-cystine on the rat plasma lipoproteins. Ann. Nutr. Metab., 28, 311-320.

SCHNEIDER A., STANGE E. F., ALAVI M., DITSCHUNEIT H., POLEY J. R., 1979. Intestinal HMGR regulation in vivo : adverse effects of cholesterol, bile acids, and lipoproteins. J. Lipid Res., 20, 1048-1049.

SHIFF T. S., ROHEIM P. S., EDER H. A., 1971. Effects of high sucrose diets and 4-aminopyrazolopyrimidine on serum lipids and lipoproteins in the rat. J. Lipid Res., 12, 596-603.

SPERRY W. M., WEBB M., 1950. A revision of the Schoenheimer-Sperry method for cholesterol determination. J. biol. Chem., 187, 97-106.

STANGE E. F., DIETSCHY J. M., 1983. Cholesterol synthesis and low-density lipoprotein uptake are regulated independently in rat small intestinal epithelium. Proc. nat. Acad. Sci. USA, 80, 5739-5743.

STRANDBERG T. E., TILVIS R. J., MIETTINEN T. A., 1983. Regulation of cholesterol synthesis in jejunal absorption cells of the rat. Scand. J. Gastroenterol., 18, 1017-1023.

SUZUKI N., FIDGE N., NESTEL P., YIN J., 1983. Interaction of serum lipoproteins with the intestine. Evidence for specific high-density-lipoprotein binding sites on isolated rat intestinal mucosal cells. J. Lipid Res., 24, 253-264.

THOMSON A. B. R., DIETSCHY J. M., 1981. Intestinal lipid absorption : major extracellular and intracellular events, 1147-1220. In L. R. JOHNSON, Physiology of the gastrointestinal tract. Raven Press, New York.

TURLEY S. D., ANDERSEN J. M., DIETSCHY J. M., 1981. Rates of sterol synthesis and uptake in the major organs of the rat in vivo. J. Lipid Res., 22. 551-569.

VENKATESAN S., MITROPOULOS A., 1982. 3-Hydroxy-B-methylglutaryl coenzyme A reductase. The difference in the mechanism of the in vivo modulation by phosphorylation and dephosphorylation to modulation of enzyme activity by non-esterified cholesterol. Biochim. Biophys. Acta, 710, 446-455.

WEISER M. M., 1973. Intestinal epithelial cell surface membrane glycoprotein synthesis. An indication of cellular differentiation. J. biol. Chem., 248, 2536-2541. 